\title{
Influence of Tritikale Grain Shelling on Flour Output for Pasta Products
}

\author{
Roman Khazhsetovich Kandrokov* \\ Federal State Budgetary Educational Institution of Higher Education "Moscow State University of Food Production", Russia
}

*Corresponding author: Roman KhazhsetovichKandrokov, Federal State Budgetary Educational Institution of Higher

Education "Moscow State University of Food Production", Russia

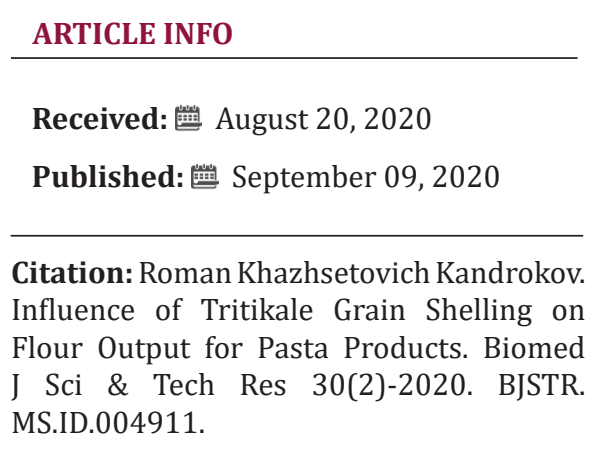

ABSTRACT

Keywords:Triticale; Peeling; Yield; Ash Content; Flour for Pasta

\section{Introduction}

Current trends in the development of flour milling both in Russia and around the world include not only the improvement of technologies for processing traditional crops (wheat, rye, buckwheat, barley, rice, oats), but also the development of new technologies for processing non-traditional crops such as triticale. Technological properties, incl. milling, baking and pasta, triticale grains are relatively little studied [1-5]. This circumstance can explain the absence of industrial flour mills for the processing of triticale into bakery flour and flour for pasta. The aim of the presented work is to study the effect of peeling of triticale grain on the yield and quality of flour for pasta.

\section{Materials and Methods}

In a study carried out at the Department of Grains, Bakery and Confectionery Technologies of FSBEI VO MGUPP, a sample of triticale grain of the Zimogor variety was used as one of the most highly glassy varieties and as the most suitable for this type of grinding. Before grinding, hydrothermal treatment (HTT) of the original triticale grain was carried out with moistening up to $16 \%$ and heating for 12 hours. Cold conditioning was used as a TRP as the most common and least costly method. Hulling of the original grain was carried out on a laboratory hulling machine manufactured by Satake (Japan). Grinding was carried out on a PCA-5 grinder and sorter with cut rollers. Sifting of the crushed product was carried out on a laboratory sieve. The enrichment of intermediate products of grinding grain of triticale was carried out on a laboratory sieve machine. The parameters and modes of grinding corresponded to the recommended "Rules for the organization and conduct of the technological process at flour mills" for high-quality grinding of wheat according to an abbreviated technological scheme.

\section{Results and Discussion}

Studies on the influence of the process of peeling of triticale grain on the yield and quality of flour for pasta were carried out according to the developed technological scheme, which consists of 5 torn, 2 grinding and 3 sieve systems. A feature of the developed technological scheme is that we combine coarse grains from I-III torn systems and enrich on the $1^{\text {st }}$ sieve system, before sending them to grinding on 1 grinding system. We combine the first exit from the second grinding system with the first exit of the III torn system and send it to regrind on the IV torn system. There we direct the descent and retraction from both sieve systems, which make up from 20 to $25 \%$. We get finished products in the form of flour for pasta on the $2^{\text {nd }}$ and $3^{\text {rd }}$ sieve systems. The $2^{\text {nd }}$ sieve system receives from 45 to 
$50 \%$ of the intermediate products of grinding grain of triticale, and the yield of enriched grains is from 35 to $43 \%$. The 3 -sieve system receives from 13 to $17 \%$ of the intermediate products of grinding triticale grain, and the yield of enriched crumbs is $11-55 \%$. The approximate yields of gritty products and flour in shredded and grinding processes during the processing of triticale grain into flour for pasta according to the developed reduced technological scheme are presented in Table 1.

Table 1: Approximate yields of gritty products and flour in shredded and grinding processes when grinding triticale of the "Zimogor" variety.

\begin{tabular}{|c|c|c|c|c|c|}
\hline \multirow{2}{*}{ System Name } & \multicolumn{2}{|c|}{ Large,\% } & \multirow{2}{*}{ Dunsty,\% } & \multirow{2}{*}{ Flour,\% } & \multirow{2}{*}{ Total recovery,\% } \\
\cline { 2 - 5 } & Large & Average and Small & $2-3$ & $6-8$ & $27-33$ \\
\hline I torn & $13-16$ & $6-8$ & $2-3$ & $4-6$ & $30-37$ \\
\hline II torn & $19-21$ & $5-7$ & $2-3$ & $3-5$ & $13-18$ \\
\hline III torn & - & $8-10$ & $6-9$ & $13-19$ & $70-75$ \\
\hline Total & $32-38$ & $19-25$ & & \\
\hline
\end{tabular}

To determine the influence of the processes of hydrothermal treatment and peeling of triticale grain on the yield and quality of flour for pasta, preparation was carried out according to three different options. The results obtained for the yields and quality of triticale grain processing products for various options are presented in Table 2. The highest yield of both flour for pasta and the overall yield with flour of the second grade was obtained according to the third option with preliminary peeling of the TRP field and peeling with the removal of about $3 \%$ of the shells. At the same time, the quality of the resulting flour for pasta is on the same level with the products of processing of triticale grain, obtained by grinding without the peeling process. The flour yield for pasta with TRP and peeling was $51.4 \%$ with an ash content of $0.81 \%$, the flour yield for pasta with TRP but without peeling was $48.9 \%$ with an ash content of $0.80 \%$, flour for pasta without TRP, but with peeling it was only $44.6 \%$ with an ash content of $1.00 \%$ (Table 2 ).

Table 2: Influence of peeling on the yield and quality of intermediate grinding products of triticale grain of the "Zimogor" variety.

\begin{tabular}{|c|c|c|c|c|c|c|}
\hline \multirow{3}{*}{ Name Product } & \multicolumn{6}{|c|}{ Indicators of the Quality of Products of Processing of Triticale Varieties "Zimogor" } \\
\hline & \multicolumn{2}{|c|}{ TRP Without Peeling Grain } & \multicolumn{2}{|c|}{ Hulled Grain Without TRP } & \multicolumn{2}{|c|}{ Hulled Grain With TRP } \\
\hline & Output, \% & Ash Content,\% & Output, \% & Ash Content, \% & Output, \% & Ash Content, $\%$ \\
\hline $\begin{array}{l}\text { Flour for Pasta }-1 \text { (315-560 } \\
\text { Microns) }\end{array}$ & 37,5 & 0,79 & 28,6 & 0,95 & 37,2 & 0,80 \\
\hline $\begin{array}{l}\text { Flour for Pasta - } 2 \\
(220-315 \text { Microns) }\end{array}$ & 11,4 & 0,81 & 16,0 & 1,09 & 14,2 & 0,85 \\
\hline Total Flour for Pasta & 48,9 & 0,80 & 44,6 & 1,00 & 51,4 & 0,81 \\
\hline $\begin{array}{c}\text { Flour Grade } 2 \\
(\text { Passage } 220 \mu \mathrm{m})\end{array}$ & 27,8 & 1,28 & 33,4 & 1,29 & 26,7 & 1,15 \\
\hline Bran & 23,3 & 3,62 & 19,0 & 3,01 & 18,9 & 3,29 \\
\hline Attitudes Peeler & - & - & 3,0 & 3,04 & 3,0 & 3,14 \\
\hline
\end{tabular}

The resulting triticale flour for pasta is characterized by a balanced composition of protein fractions. The product has a good presentation with a predominance of opaque white powdery grains with the presence of translucent ribbed cream-colored grains. In addition, porridge made from triticale groats of the "semolina" type has high culinary advantages. The cooking time is 8-10 minutes, the color of the porridge is white-grayish, the consistency is homogeneous, it has a pleasant taste characteristic of porridge made from soft wheat.

\section{Output}

Based on the results of the research, a technology for processing triticale grain into flour for pasta has been developed. It has been established that the highest yield of triticale flour for pasta is obtained when using the peeling process with removal of about $3 \%$ before grinding, while it is recommended to carry out hydrothermal treatment of triticale grain before the peeling process.

\section{References}

1. Kandrokov RKh, Starichenkov AA, Steinberg TS (2015) The influence of the TRP on the yield and quality of triticale flour. Bread products 1: 6465.

2. Kandrokov RKh, Pankratov GN (2017) Technology of processing triticale grain into semolina type cereals. Bread products 1: 52-53.

3. Kandrokov RH, Pankratov GN, Meleshkina EP, Vitol IS, Tulyakov DG (2019) Effective technological scheme for processing triticale grain into high-quality baker's grade flour. Foods and Raw Materials 7(1): 107-117.

4. Pankratov GN, Kandrokov Rkh (2017) Investigation of the process of enrichment of crumbs during high-grade grinding of triticale grain. Food Industry 7: S30-33.

5. Kandrokov RKh, Pankratov GN (2017) Pat. 2612422 Russian Federation, IPC B02C 4/06 Method of production of flour from triticale grain [Text]. Applicant and patentee VNIIZ - branch of the Federal State Budgetary Scientific Institution "Federal Research Center of Food Systems named after V.M. Gorbatov"RAS. - No. 2612422. 


\section{ISSN: 2574-1241}

DOI: $10.26717 /$ BJSTR.2020.30.004911

Roman Khazhsetovich Kandrokov. Biomed J Sci \& Tech Res

(C) This work is licensed under Creative

Submission Link: https://biomedres.us/submit-manuscript.php

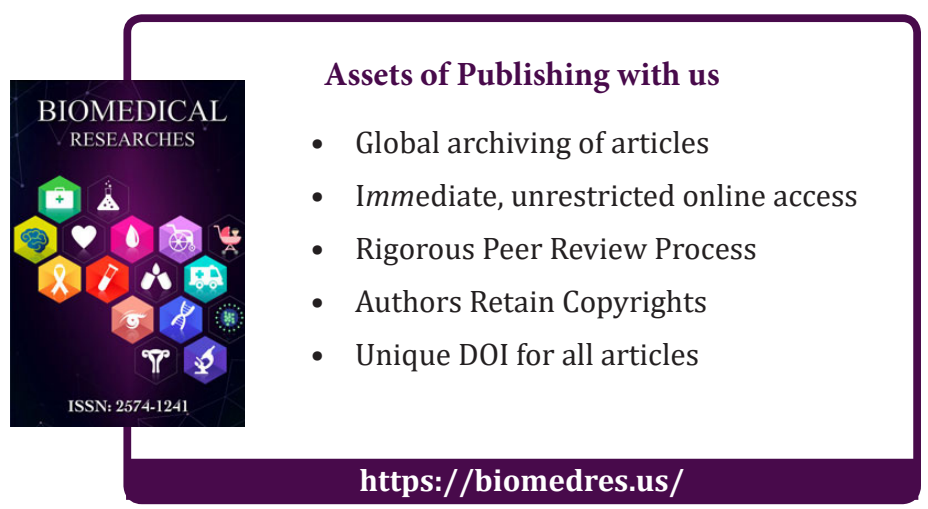

